\title{
MONTESSORI METHOD AS A BASIS FOR INTEGRATED MATHEMATICS LEARNING
}

\author{
Jasmina Milinković, $P h D$ \\ Teachers Training Faculty, Belgrade (Serbia) \\ e-mail: jasmina.milinkovic@uf.bg.ac.rs \\ Dragana Bogavac, PhD \\ Teachers Training Faculty, Belgrade (Serbia) \\ e-mail: dragana.bogavac@uf.bg.ac.rs
}

\begin{abstract}
This research offers a theoretical comparative analysis of the Montessori Method and integrative teaching. Current trends call for incorporation of an integrative approach into educational practice. From the constructivists' cognitive perspective knowledge is constantly changing, and results from acting and thinking. Maria Montessori developed an approach which is intellectually challenging and motivating. It develops a creative, flexible, authentic and constructive personality. In this paper we focus on theoretical aspects of both Montessori Method and integrative approach and look for compatible elements. We pay special attention to effects of the Montessori Method on development of mathematical aspects of reasoning.

Our argument is that preschool Montessori Method has the capacity to become the basis for an integrative school approach. This provides a smooth move from early childhood learning to school learning. We point to the similarity of learning goals. Also, we pay attention to features of productive environments created within these two Methods for mathematics learning. In the light of the analysis, we suggest common features of the Montessori Method and integrated curriculum approach which have positive effects on mathematics learning. Finally, we draw some educational and curricular research questions. Our argument is that the Montessori Method presents natural prerequisites for integrated learning. We conclude that together they fulfil the social need for functional knowledge and holistic approach to a child's development.
\end{abstract}

Key words: Montessori Method, integrated learning, mathematics

\section{Introduction}

At the beginning of our discussion on the Montessori Method and integrative learning let us define a principle idea followed in our work. First, we assume that knowledge is socially constructed. Development of the process of thinking and building knowledge occurs in a social environment. The two processes are shaped by culture and evolve and change in interactions of individuals with other persons and cultural tools. Both the Montessori Method and integrative approach are rooted in problem solving. The intention to solve problems is a motivation for learning and it provides context for learning. 
In effect, learning becomes the means in problem solving. We paid a closer look at the Montessori Method and at integrative learning in search for gaining insight on how to help children develop as whole persons starting from kindergarten to adulthood.

National documents on school curriculum define goals and objectives for elementary school mathematics. They maintain that among others skills and knowledge, schools should develop in pupils "the ability to recognize, formulate, analyze and solve problems". In order to be able to solve a problem, pupils need to develop the ability "to separate important from unimportant information, to give argumentation, to prove claims, to distinguish between scientific from experience based (subjective) approach to solving problem, to assess progress and to analyze the problem from different angles (mathematics, physics, technology, etc)" (Ministry of Education and Sports of the Republic of Serbia, 2003, p. 58). The National document on school curriculum also calls for effort in developing pupils' ability to perform simple experiments. These requirements should be reconsidered in the light of teaching approach from early years throughout the school system.

\section{Integrated mathematics curriculum}

In the paper we focus on integrative elements of mathematics education in elementary school. The concept of integrated curriculum coincides with a holistic view of education as a complex system with a unique goal. It produces a complex, holistic view of world in children. As a result children look for connections and relations among phenomena in search for understanding or in process of problem solving (Vilotijevic, 2008). In the integrated curriculum, a (realistic) context provides opportunity for extended learning experience and or making connections and transfer. Usage of a rich ill defined problem situation leads pupils to identify problems and then develop a plan for resolving the issue which calls for making connections and transfer of knowledge (Milinkovic, 2009) The main objective in the integrative approach is to facilitate development of holistic approach to problems and cohesion and connection of functional knowledge (Milinkovic, 2009). Pupils' active learning through problem solving is a basic assumption. "The Integrative Approach insists on projects rather than on individual mathematics units with strictly defined content" (Flamand). When making connections and finding relations among various concepts, children achieve individually set objectives and standards. Let us remark that one important goal of the integrative approach is to allow children to develop a multifaceted view of problems. As Gudjonson stated integrative learning has a "tendency to be interdisciplinary." (Gudjonson, according to E. Terhart, 2001, p. 186)

The origin of blending topics from different mathematical fields, or from different scientific fields may be traced to the Old Greek civilization. For example, Euclid in books sixth, seven and eight of Elements defines numbers as geometric concepts. (E.g. Even number is the one which can be measured in two equal parts). But as body of knowledge grew bigger, scientific fields separated and this was followed by setting limits of school subjects. Nowadays, we can talk about call for reunion of schools subjects into a unique body of knowledge and values that need to be passed on to young generation. Our highly technical society requires from individuals to have strong knowledge base that is flexible, connected, and highly adaptable to different contextual usage. 
However, educational systems are still strictly divided into subject areas. The school curriculum does recommend sharing instructional units or school time in common activities involving two or more subjects but this rarely happens in practice. Even if the subject curricula do overlap, teachers would be more willing to repeat instruction on the same content twice than to decide where would be more appropriate to teach the content. In particular, although the idea of integrated mathematics curriculum is not a new one in contemporary educational practices (McGraw, 2003), we may notice that it is neither fully explored nor generally appreciated as important in teaching practice.

When considering the issue of integration of mathematics we could talk about integration at a level of studying a particular problem, lesson, unit, strand, subject or curriculum. In the domain of mathematics, as House, (2003, p. 5) explains, it implies holistic mathematics curriculum where 1) topics from wide variety of mathematical fields have been blended to stress connections among fields; or/and 2) relationships among topics within mathematics as well as between mathematics and other disciplines have been underlined... Within integration of mathematical topics we may further distinguish (a) integration through unifying concept, such as function or mathematical modelling, (b) integration by merging areas (strands) of mathematics.

There were few attempts to create integrated mathematics curriculum from elementary school to high school curriculum worldwide. We have no intention to provide historical overview from the Chicago project of J. Dewey to contemporary practice. Let us mention only some of more resent projects created for Middle school: Connected Mathematics, Jasper (van Haneghan, J., Barron. L., Young, M. \& Williams, N. V., 1992), MathScape: Seeing and Thinking Mathematically, Pathways to Algebra and Geometry, Math Trailblazers (Elementary School, K-5) and Mathematics in Context. For example, the Core-plus Mathematics Project has developed a mathematics curriculum with proclaimed goal to achieve ,integrative development of basic concepts and skills". In particular, they developed units for independent studying of important mathematical ideas in realistic problem solving context, often recognized as applied mathematics. Similarly Interactive Mathematics Program (IMP) presents set of textbooks for "learning mathematics with understanding through integrated, problems oriented learning". Finally, Mathematics in Context (Romberg et al., 1998) curriculum is focused on the process of mathematization of realistic situations. Here, led by ideas developed by the Fraudenthal Institute, the authors created units around contextual problems relevant to children with attention to both horizontal and vertical process of mathematization. Thus, each unit deals with a realistic context which elicits learning of different mathematical concepts from different strands and making connections with other subject domains. These are exemplary cases of contemporary mathematics curriculums with the common goal of integrating contents while placing students in an active position in learning.

In Serbian educational practice we found only a few attempts of implementation of the integrative curriculum. N. Vilotijevic (2006) provided arguments for integrative approach to science learning in Grades 1 to 4 in elementary school. Complementary, she presented a set of exemplary lessons of integrative curriculum. Milinković (2009) reports on results of an experimental study on integrated mathematics and technology in the $5^{\text {th }}$ Grade. Pupils learned elements of statistics while studying performance of paper planes during classroom competition. Other examples of integrated learning in elementary and high school are present in bilingual classrooms. For example teachers of Mathematics, Music, 
Physical Education and Technology teach their subjects in English to $7^{\text {th }}$ and $8^{\text {th }}$ Grade pupils in experimental classrooms in "Starina Novak" elementary school in Belgrade. Similarly, $1^{\text {st }}$ and $2^{\text {nd }}$ Grade pupils of "The Third High School" in Belgrade learn Latin and few other subjects in the Italian language.

\section{Mathematics in Montessori approach}

Montessori approach affirms that a good, agreeable environment is characterized by: 1) accessibility, 2) freedom of movement and choice, 3) self responsibility, 4) realistic/natural ambience for learning, 5) beauty and harmony. Accessibility implies that an environment in which children spend time must be designed in such a way that size of furniture fits children and that a child may freely use open space on the floor for group and individual play. It also implies good, well structured organization of didactical tools and activities classified on open shelves according to learning content domains. It fits gradual increasing complexity of activities as well as ascending levels of skill's acquisition. Thus, materials must be on a plate, in a basket or in a box with all necessary utensils included so that a child may have granted access to it any time for independent work on it. The completeness of "toys" makes the context for work with them predictable so that child may freely focus on work with the toy. Promising surrounding is the one which provides wide range of activities and allows free choice of movement and activities to children. Maria Montessori believed that freedom of movement and independent choice of activity goes well together. Note that she strongly believed that the child should not be restricted on how many times she/he desires to repeat an activity during a single day or during a period of time.

The child could also choose to observe others instead of playing with a certain didactical toy. However children need to be cooperative to a certain extent because any interest of a group is more important than the interest of individuals. In other words, community has priority over persons who are members. But if we remember how important social environment is and that knowledge is socially constructed, we will appreciate social life of individuals. Quite often, we could observe that older children educate youngsters by sharing an activity or helping them in a play when needed. Realistic/natural context for learning assumes the imperative of standard of perceptibility. Didactical tools need to be starting point for exploratory work. Finally, an important characteristic of a pleasurable ambient is beauty and harmony and simplicity which need to characterize the space so that children can enjoy spending time in it.

As we can see, the Montessori ambient provides special resources also for children requiring adapted conditions presents a unique environment. In particular, it is supportive for exploration and early discovery of mathematical ideas and relations as well as for development of mathematics reasoning.

Since the Montessori didactical materials often hide different problems, they can be used in various ways and help development of different mathematical ideas. Let us point that preschool children are free from particular subject domain knowledge. In other words, they may apply whatever knowledge they find appropriate for resolving the problem. However, when a problem is given with transparent subject domain limitations, we cannot expect integration of knowledge. There was no procedure for resolving ill defined problems 
that could be applied in a given context. Children need to invent the procedure for solving problem themselves (with little help of their preschool teacher).

The Montessori Method of education involves three key components: child, teacher and setting. Maria Montessori insisted that it was very important that adults believed in children's ability. She also strongly believed that well designed safe surrounding supported learning process.

If we pay attention to early mathematics, we should know that Maria Montessori believed that for intuitive development of mathematics reasoning children had to be placed in an environment which appealed to children to recognize regularities and patterns as well as to classify and quantify. These, she believed, represented major issues in mathematics. Learning of mathematics is a result of process of abstraction similarly to learning elements of other subject domains. Didactic materials lead children to acquisition of knowledge.

For example, building up the "Pink tower" leads child to recognition/discovery of the idea of regularity and order. Another example is classification with shapes from the "Geometrical cabinet". It leads children to make a distinction between various regular geometrical shapes. Again, the process of active learning leads children to the idea of quantity trough measurement and estimation. One more example is a tool called "Arithmetic sticks". It fosters development of relation between quantity and dimension.

Barbara Isaacs (2007) analyses elements of mathematics addressed in the Montessori approach. Her tables below illustrate how Maria Montessori envisioned spontaneous development of mathematical ideas and mathematical reasoning. The first table presents development of numbers and counting. The second table presents development of ideas of shape, space and measures.

\begin{tabular}{|c|c|}
\hline Numbers as labels and for counting & Montessori practice \\
\hline $\begin{array}{l}\text { Children: } \\
\text { say and use numbers' names in order in a } \\
\text { familiar context; }\end{array}$ & $\begin{array}{l}\text { Children: } \\
\text { join in rhymes and use counting books and } \\
\text { count shoes, the number of children present } \\
\text { and days of the week; }\end{array}$ \\
\hline count reliably up to ten everyday objects; & $\begin{array}{l}\text { count number rods, pegs, spindles, counters } \\
\text { and other objects in the environment; }\end{array}$ \\
\hline recognize numerals 1 to 9 ; & $\begin{array}{l}\text { use sandpaper numerals and a spindle box, } \\
\text { number cards, birthday display and calendar; }\end{array}$ \\
\hline $\begin{array}{l}\text { use developing mathematical ideas and } \\
\text { Methods to solve practical problems. }\end{array}$ & $\begin{array}{l}\text { play the Snake Game to make number } \\
\text { bonds of ten, play dominoes, and make } \\
\text { symmetrical, regular and irregular } \\
\text { structures; } \\
\text { are helped to find out what happens if } \\
\text { objects are organized in pairs or sets or } \\
\text { taken away. }\end{array}$ \\
\hline \multicolumn{2}{|l|}{ Calculating } \\
\hline $\begin{array}{l}\text { in practical activities and discussions, begin to } \\
\text { use the vocabulary involved in adding and } \\
\text { subtracting; }\end{array}$ & $\begin{array}{l}\text { are introduced to the concept of addition and } \\
\text { subtraction within everyday activities in the } \\
\text { classroom, such as artwork and building with } \\
\text { blocks; }\end{array}$ \\
\hline $\begin{array}{l}\text { use language such as 'more' or 'less' to compare } \\
\text { two numbers; }\end{array}$ & $\begin{array}{l}\text { count the number of spoons or raisins or } \\
\text { biscuits taken at snack time or lunch time } \\
\text { and count in the context of everyday }\end{array}$ \\
\hline
\end{tabular}




\begin{tabular}{|c|c|}
\hline are introduced to the appropriate language & $\begin{array}{l}\text { activities such as circle time or going outside; } \\
\text { in the context of everyday activities; }\end{array}$ \\
\hline $\begin{array}{l}\text { find one more or one less than a number } \\
\text { from one to ten; }\end{array}$ & $\begin{array}{l}\text { use a number line, short bead stairs and the } \\
\text { addition and subtraction strip board to count } \\
\text { and explore numbers; }\end{array}$ \\
\hline $\begin{array}{l}\text { begin to relate addition to combining two } \\
\text { groups of objects and subtraction to 'taking } \\
\text { away'. }\end{array}$ & $\begin{array}{l}\text { are introduced to the Snake Game and } \\
\text { addition and subtraction with short bead stairs } \\
\text { and play counting games such as Greengrocers. }\end{array}$ \\
\hline Shape, space and measures & Montessori practice \\
\hline $\begin{array}{l}\text { - use language such as 'greater', 'smaller', } \\
\text { 'heavier' or 'lighter' to compare quantities; }\end{array}$ & $\begin{array}{l}\text { use and compare sensorial materials to explore } \\
\text { length, height, width and depth; use appropriate } \\
\text { vocabulary in everyday context, such as when } \\
\text { cooking, setting table or gardening; }\end{array}$ \\
\hline $\begin{array}{l}\text { - talk about, recognize and recreate simple } \\
\text { patterns; }\end{array}$ & $\begin{array}{l}\text { use of tessellations and constructive triangles } \\
\text { and materials (such as collage) in the art area } \\
\text { to make patterns; do puzzles and work with } \\
\text { unit blocks; }\end{array}$ \\
\hline $\begin{array}{l}\text { - use language such as 'circle' or 'bigger' to } \\
\text { describe the shape and size of solids and flat } \\
\text { shapes; }\end{array}$ & $\begin{array}{l}\text { play mapping games, play with blocks and play } \\
\text { outdoor games in the playground and during } \\
\text { music and movement activities; }\end{array}$ \\
\hline
\end{tabular}

Table 1

\section{Comparative discussion on two methods}

The Montessori approach is discussed here not only as a prerequisite for integrative learning in school. We believe that the Montessori approach promotes integrative learning within preschool program. To support our stand we point to some examples of integration. An interesting example of integrative learning used in the Montessori Method is a case of integration of arithmetic and geometry. One issue is how to learn that a digit may have different values depending on a place it has in a multidigit number? Another issue is how to understand relations among dots, lines and planes? The third issue is how to put the previously mentioned two issues together? Complex notification in Descartes system, discovering place value and 1-, 2-, and 3-dimensional objects develop trough the "game with golden pearls". One more example has been already mentioned. Earlier in the paper, we described attempts to achieve integrative learning of the concept of numbers and of lengths in the game with "Arithmetic sticks".

Now we can explain our claim about commonalities of goals and means for learning in Montessori Method and integrative learning. Both the integrative approach and Montessori Method aim for development of higher thinking processes such as creative reasoning and transfer. Constructing knowledge in integrated learning has advantage over obtaining facts. Such goal with shifted weigh toward encouraging and tending innate desire for learning is a characteristic for Montessori approach as well.

One of our main ideas relates to plausible environment for learning. Montessori approach as we could see provides stimulating environment for learning by making it free of distracting elements. We may think about learning environment in terms of levels of 
distracting elements that it possesses. Montessori environment might be defined as first level of environment free of distracting elements. The second level is integrative school learning where we do have distracting elements which simulate realistic context. But unlike real context, a problem on which children are working on is defined by subject matter. On this level exploratory approach to learning is more demanding. The problems require higher mental skills. Because there are more distracters the position of child is somewhat changed. The child need to percept, to extract and analyses information that might be useful in solving given problem. Then the child needs to make conclusions and finally make discoveries. The ending result sometimes brings up new ideas and becomes the first step in solving next problem, as much as the initial problem has had in Montessori Methods. At the third level a real life-work situation contexts where an individual explores and learns is full of distracters.

We ask ourselves what elicits interest in children to learn more or to try to solve new problem. Perhaps it is a feeling of free choice. "I learn because I wish to do so and I feel I can do it in my way." Education process offers a lot self organization and self responsibility on the second and the third level. They are imperative for successful problem solving process, whereas at the first level children appear less independent. We may say that at the preschool level of activities in Montessori Method we may talk about co-organization and co-responsibility since they are shared with the preschool teacher. Within educational system such as the preschool system and school system, educational activities are goal oriented. We may talk about general educational goals as well as day to day goal educational activities. We may compare educational goals from the table.... But here we need to distinguish between teacher's educational goals for learning and child's goal for acting. To exemplify, a teacher might have a goal to teach children that a certain geometrical shape could be seen as a puzzle made of other geometrical shapes. In particular, a square can be seen as a unity of two equilateral right triangles. Whereas a child could have a goal to make a boat or to make as many different shapes as possible with given number of puzzle pieces. The teachers' learning goal and child's activity oriented goal together bring the child to achieving a standard for learning such as standard for mathematical critical thinking and reasoning. Finally, on the third level, in real life situation the person is completely independent.

At all three levels of integrative learning, starting from the Montessori level across school integrative learning toward spontaneous real problem solving in life, we teach appropriate potential of experience from concrete acting to conceptual understanding.

Here are some of the questions remaining after our paper.

1. Is the Montessori approach the only authentic basis for integrative approach in school? 2. Is integrative learning approach in school the only natural successor of the Montessori Method? Does integrative learning approach have limits? In other words, can we achieve more than functional knowledge? 


\section{Bibliography}

House, P. A. \& Coxford, A. F. (1995) Connecting Mathematics across the Curriculum, 1995 Yearbook. NCTM.

Isaacs, B. (2007) Bringing the Montessori approach to your Early Years Practice. Rootled, London

Kozulin, A. (1986) Vygotsky in context. In L. S. Vygotsky, Thought and language, pp. xi-lvi. The Massachusetts Institute of Technology.

Leontiev, A. N. (1981) Problems of the development of the mind. Moscow: Progress.

Loepp, F. L. (1999) Models of curriculum integration. The journal of technology, XXV, 2, 1-7 (electronic journals)

McGraw, S. A. (2003) Integrated Mathematics: Choices and Challenges. NCTM: Reston, VA

Milinković, J. (2009) Pupils' active learning in integrated mathematics and technical education class: a case study. In I. Radovanović and Z. Zaclona (Eds) Student in Contemporary Learning and Teaching, 97-109. Uciteljski fakultet, Beograd curriculum

Ministry for Education and Sport of Republic of Serbia. (2003) The foundation of school

Romberg et al. (1998) Mathematics in context: a connected curriculum for Grades 5-8. Encyclopedia Britanica

Terhart, E (2001) Metode poučavanja i učenja: uvod u problem metodičke organizacije poučavanja i učenja. Zagreb: Educa (translated in Croatian)

Tudge, J. \& Rogoff, B. (1989): Influences on cognitive development: Piagetian and Vygotskian Perspectives. In M. H. Bornstein \& J. S. Bruner (Eds.) Interaction in Human development, 17 - 39. Hillsdalle, NJ: Lawrence Erlbaum Associates, Publishers.

Van Haneghan, J., Barron. L., Young, M. \& Williams, N. V. (1992) The Jasper Series: An experiment with new ways to enhance mathematical thinking. In D. F. Halpern (ed) Enhancing thinking skills in the sciences and mathematics (pp 15-35)

Vygotsky, L. S. (1986) Thought and language. The Massachusetts Institute of Technology

Wertsch, J. V. (1985): Culture, Communication, and Cognition: Vygotskian perspectives, 1 - 18. New York: Cambridge University Press

Vilotijević, N. (2006) Integrativna nastava prirode i drustva. Beograd: Školska knjiga

Vilotijević, N. (2008) Sistemsko-teorijske osnove integrativne nastave. Metodička praksa, 4, 79 96. Beograd, Učiteljski fakultet 
Metodički obzori 6(2011)1

Pregledni rad

UDK: $371.4 \mathrm{Mon}$

Primljeno: 13. 11. 2010.

\title{
MONTESORI METODA - OSNOVA INTEGRISANOG UČENJA
} MATEMATIKE

\author{
Dr. sc. Jasmina Milinković, \\ Učiteljski fakultet, \\ Univerzitet u Beogradu (Srbija) \\ e-mail: jasmina.milinkovic@uf.bg.ac.rs \\ Dr. sc. Dragana Bogavac, \\ Učiteljski fakultet, \\ Univerzitet u Beogradu (Srbija) \\ e-mail: dragana.bogavac@uf.bg.ac.rs
}

\section{Rezime}

Rad nudi teorijsku komparativnu analizu Montesori metode i integrativne nastave. Savremene tendencije ukazuju na potrebu uključivanja integrativnog pristupa u obrazovnu praksu. Sa stanovišta konstruktivizma znanje se neprestano menja i rezultat je akcije i razmišljanja. Marija Montesori je razvila metod koji je intelektualno provokativan i motivišući. Njime se razvija kreativna, fleksibilna, autentična i konstruktivna ličnost. U ovom radu, mi smo se fokusirali na teorijske aspekte obe metode: Montesori metode i integrativne metode tražeći kompatibilne elemente. Posebnu pažnju posvetili smo efektima Montesori metode na razvoj matematičkog mišljenja.

Mi pružamo argumentaciju u prilog teze da predškolski Montesori pristup ima kapacitet da bude osnova integrativnog učenja u školi. On predstavlja gladak prelazak sa ranog učenja na školsko učenje. Ukazujemo na sličnost ciljeva ucenja. Takodje, posebnu pažnju posvećujemo sredini kreiranoj u ova dva pristupa posebno pogodnoj za učenje matematike. U svetlu date analize, ukazujemo na zajedničke osobenosti Montesori metode i integrativne metode koji imaju pozitivan efekat na učenje. Konačno, mi ukazujemo na neka obrazovna i kurikularna istraživačka pitanja. Naš stav je da Montesori metoda predstavlja prirodnu osnovu za integrativo učenje. Zaključujemo da zajedno one mogu ispuniti potrebu društva za funkcionalnim znanjima i holističnim razvojem dece.

Ključne reči: Montesori metoda, integrisano učenje, matematika 